\title{
An Action Research on College English Teaching Aiming at Improving Students' Intercultural Consciousness
}

\author{
Ji-Nan $\mathrm{Jia}^{1}$ \\ ${ }^{1}$ School of Foreign Languages, Inner Mongolian University for Nationalities, Tongliao, Inner Mongolian, China \\ Correspondence: Ji-Nan Jia, School of Foreign Languages, Inner Mongolian University for Nationalities, \\ Tongliao, Inner Mongolian, China. E-mail: jiajinan@imun.edu.cn
}

Received: December 2, 2014 Accepted: January 10, 2015 Online Published: February 25, 2015

doi:10.5539/ells.v5n1p119 URL: http://dx.doi.org/10.5539/ells.v5n1p119

\begin{abstract}
Through a questionnaire survey, the study applies action research to intercultural college English teaching in Inner Mongolia University for the Nationalities, for the sake of proving the effectiveness of the teaching approach "Cultural Knowings" and raising English learners' intercultural awareness. It finds problems in the teaching and verifies them, then designs feasible teaching strategies and carries out experimental teaching, and finally figures out the matters that should be taken into account in intercultural teaching.
\end{abstract}

Keywords: intercultural teaching, intercultural consciousness, college English teaching

\section{Introduction}

According to the Outline of National Medium and Long-Term Program for Education Reform and Development (2010-2020), education should "adapt to the opening-up policy of Chinese economy and society, cultivate a large number of internationalized personnel who have global perspectives, are familiar with international rules, and are able to participate in international affairs and competitions." Internationalized personnel should be armed with many essential qualities, such as solid language skills, good intercultural communication abilities, broad international perspectives and generous patriotic feelings for China. College English teaching, as an integral part of Chinese higher education, should keep pace with the times, exercise the function of English as an international language "communication tool" and "culture carrier" and effectively integrate basic language skills, language use, culture learning and communication skill training to realize the leaping development of intercultural teaching in college English teaching. Then what kind of intercultural teaching mode can effectively improve students' intercultural competence, especially intercultural consciousness? Based on the development process of cultural teaching and the characteristics of intercultural teaching, this paper is to prove the effectiveness of the intercultural teaching mode known as "Cultural Knowings" by taking the approach of action research.

\section{Overview of Past Research on Intercultural Teaching}

Cultural teaching is derived from sociologists' and linguists' profound understanding of the relationship between language and culture. As early as 1921, Sapir pointed out that language cannot be isolated from culture. Language expresses, embodies and symbolizes cultural realities (Kramsch, 1998, p. 3). Any language teaching mode cannot be implemented without cultural teaching, because language is deeply rooted in culture, and language is the carrier of culture.

Although there are great differences between countries and regions in their language teaching modes due to different social environments and education systems, their cultural teachings have gone through three stages of development without exception. (1) In the 1950s and 1960s, cultural teaching was dominated by reading literary works, and historical figures and major cultural events about the culture of the target language, known as the "big culture" all together, were incorporated into teaching materials. Students learnt about the culture of the target language by reading and analyzing literary works. The audio-lingual method in the US and the audio-visual approach in Europe had been prevalent since the late 1960s, during which culture acted as a stimulus to foreign language vocabulary learning. (2) In the 1970s and 1980s, culture was expressly incorporated into the teaching content of communicative language teaching, and it was a consensus between foreign language teachers and learners that the development of language skills and cultural competence was an important guarantee for improving intercultural communicative competence. During this stage, cultural teaching was 
dominated by what is known as "little culture", that is, cultural content contained in the daily life of the target language; special attention was given to cultural differences that may cause misunderstandings and failures in communication (Zhang, 2007, p. 179). Obviously, cultural teaching showed a remarkable development in this stage compared with the first stage, but it was still attached to language teaching, lacking an independent system. (3) Since the 1990s, cultural teaching has obtained an equally important position as language teaching. Cultural teaching not only provides real contexts for language teaching to improve learners' language skills and communicative competence; but also enables learners to understand the target language culture and reflect on their native culture, thus strengthening learners' intercultural consciousness. Culture learning in this stage is no longer limited to cultural knowledge learning, it also involves adjustments to emotional attitudes and changes in behaviors.

The three stages of cultural teaching also reflect the continual update of cultural teaching methods. Crozet et al. (1999) summarized four cultural teaching methods: traditional cultural teaching (or generalized cultural teaching); cultural research or regional research teaching; the teaching in which culture acts as action or social norm, and; intercultural language teaching. There are common weaknesses in the former three methods. Firstly, they focus on the static cultural realities of a target language, such as history, traditions, religions, values, social organizations and customs while ignoring the changing characteristics of the culture. Secondly, they exclusively emphasize the learning of the cultural knowledge of a target language while no intercultural comparison or reflection is made; and teaching aims at making learners of a foreign language similar to the native speakers of a target language in the way of language, speech and behavior, so learners' prejudice against the culture of a target language are very likely to become entrenched.

Unlike the former three methods, intercultural language teaching trains students' integrated ability to understand the uniqueness and universality of a culture by stressing on the deep understanding and sympathy of the unique history, literature, art, custom, view, community and members of a culture and the deep understanding of the universal concepts of a culture, including the analysis and culture simulation of major events rather than the mere instruction of the knowledge of another culture in classroom or the training of students' ability to behave well in another culture (Moran, 2001). The key to intercultural language teaching is to train learners into intercultural speakers or mediators and increase their intercultural consciousness, endow them with multiple identities and avoid stereotyped attitudes towards non-native cultures due to their single identity (Byram et al., 2002). For this reason, Liddicoat (2004) argue that intercultural language teaching should include four major cultural activities, namely cultural learning, culture comparison, cultural exploration, and the identity of intercultural "third party". To achieve the above goals, intercultural teaching should follow a set of principles. Firstly, dominant culture is a central part of language teaching. Secondly, cultural knowledge should be integrated into the teaching of other language skills rather than being taught as a separate skill. Thirdly, cultural teaching should begin and synchronize with language teaching. Fourly, cultural teaching aims at training adaptable bilinguals in intercultural environments. Fifthly, language learning should provide opportunities for learners to reflect on their own language and culture, and provide conditions for them to get rid of ethnocentric ideologies. Sixthly, cultural complexity determines the complexity of cultural acquisition, and classroom cultural teaching should help learners to make continuous learning by developing their intercultural consciousness.

\section{Definition of Action Research and Implementation Steps}

Action research was firstly conceptualized by the pioneering social psychologist Kurt Lewin. Action research is described as a way of studying a social system while attempting to change that system (Hart \& Bond, 1995, p. 13). Lewin (1948) points out that action research is spiral cycles consisting of three major phases: planning, action and reflection. Modern action research has expanded into the field of education. Kemmis and McTaggart (1982) redefined action research as follows, "Action research is a kind of study by means of self-reflection. The most basic feature is to combine action with research, verify theories and improve teaching in practice, in order to increase the understanding of the syllabus, teaching and learning and better interpret and test the current teaching theories." Action research requires teachers to serve as researchers, make the classroom a laboratory and identify problems in teaching and seek effective solutions to improve teaching quality. The whole study keeps going on and on endlessly with an upward trend. In conjunction with the definition of action research, Ferrance (2000, p. 9) further summarizes five steps in action research: problem identification, data collection and collation, analysis of data, execution of action, and reflection. We made an action research on intercultural teaching mode according to these five steps. 


\section{Action Research on Intercultural Teaching}

\subsection{Problems in Intercultural Teaching}

Many years of experiences in college English teaching make us aware of non-English majoring college students' poor English cultural competence and intercultural consciousness due to China's long-term lag in intercultural teaching. The particulars are as follows. Firstly, some students mistakenly believe that cultural knowledge is not included in the outlines of major English tests (such as TEM-4 and TEM-8), and they take a reluctant and passive attitude towards cultural learning; Secondly, students' understanding of English cultural knowledge is limited to surface culture, such as literature, history, customs, traditionsand major festivals, while they know little about deep culture, such as rules of communication, ways of thinking or values. Thirdly, under the influence of stereotypes of their mother tongue, most of them tend to think from the perspectives of Chinese culture in oral or written English. The above issues hinder students from making further improvement in intercultural competence and integrated language proficiency.

\subsection{Data Collection and Analysis}

To verify the above issues, we chose 56 English majoring students from two classes of the Foreign Languages School, Inner Mongolia University for The Nationalities as the objects of this study and implemented the first intercultural consciousness test in these classes in the first week of the second semester of the school year 2013-2014. Intercultural consciousness means the transformation from "ethnocentrism" to "ethnorelativism" and the ability to view an issue through the eyes of another person and "empathize" with and recognize the fact that dynamics of communication can lead to intercultural changes in person and society (Frederique \& Pascaline 2005). The test tool is an intercultural consciousness scale. The scale is of high validity and reliability because it was made based on FeiXiaojia's intercultural consciousness test table (2006, pp.72-74) and the intercultural communication scale of Neuliep and McCroskey (1997). The scale consists of two parts: personal information and consciousness test. The first part, in the form of blank filling, includes personal questions about age, English score in college entrance exam and past experiences in communicating with foreign nationals and so on. The second part was designed in five-point Likert Scales with an intermediate value of 3. 43 questions are included in this part to test students' non-linguistic behaviors, linguistic behaviors and cognition of intercultural teaching respectively. To make the test results as objective and factual as possible, we made a statement to the students before issuing the questionnaire that the test data would be for research purposes only and do not affect their academic attainment. Data obtained would be analyzed by SPSS17.0 software (see Table 1).

Table 1. Intercultural consciousness test results before teaching

\begin{tabular}{llll}
\hline & Question No. & Average Value & Standard Deviation \\
\hline Non-linguisticBehaviors & 7 & 2.87 & 0.78 \\
Linguistic Behaviors & 9 & 2.76 & 0.69 \\
Cognition of Intercultural & 16 & 2.83 & 0.71 \\
Teaching & 32 & 2.82 & 0.73 \\
Total & & & \\
\hline
\end{tabular}

As shown in Table 1, the average value of all tested aspects in the second part is less than 3, indicating that the participants had little understanding of intercultural communication skills, and they failed to perform good non-linguistic or linguistic behaviors in intercultural environments, and they did not show much interest in intercultural teaching and lacked the knowledge of methods and purposes of intercultural teaching. The results verified students' poor intercultural consciousness. Through communication with students after class, we discovered the causes of the issues. Firstly, there were few opportunities available for intercultural communication. The vast majority of students said that they had few opportunities for face-to-face contact with people from English-speaking countries although they had studied English for many years; they believed that there was no need to learn the knowledge of Western cultures or understand Western values because they would stay in China after graduation. Secondly, they were complacent with their own national culture and had a parochial attitude towards foreign cultures. Some students believed that the invasions of foreign films, music, drinks and food posed a threat to China's traditional culture in today's society as China becomes more open, and that too many efforts in learning foreign cultures did not mean equal cultural exchanges but the erosion of traditional culture. Thirdly, they lacked confidence in their oral English proficiency and were too shy to or even refuse to communicate with foreigners. Fourthly, they lacked efficient cultural learning resources and believed that cultural knowledge was extensive and it was hard to know where to start learning. 


\subsection{Intercultural Action Teaching}

To resolve the issues reflected in the test data, we decided to conduct intercultural action research on the objects of this study. The research lasted one school year from September 2013 to June 2014. The teaching materials adopted in this study were the Integrated Skills of English published by China's Higher Education Press. According to the characteristics of intercultural teaching and the principles that should be followed, teaching activities were centered around the theme of each unit and were divided into four aspects according to Moran's cultural learning mode of "Cultural Knowings" (2001, p. 8), that is, knowing about, knowing how, know why and knowing oneself (see Figure 1): (1) Description of cultural information: teachers select and explain the cultural knowledge; (2) Case study: teachers select the theme-related cultural events or cases to explain and summarize hidden ways of thinking or values etc.; (3) Participation in communication activities: teachers create scenarios that are closer to realities of the targeted culture and organize students to carry out intercultural communication, allowing students to gain intercultural experiences; (4) Reflection on cultural differences: teachers ask students to discuss in groups the cultural differences between Eastern and Western cultures and make learning portfolios after class to have a better understanding of learning themes and their native culture.

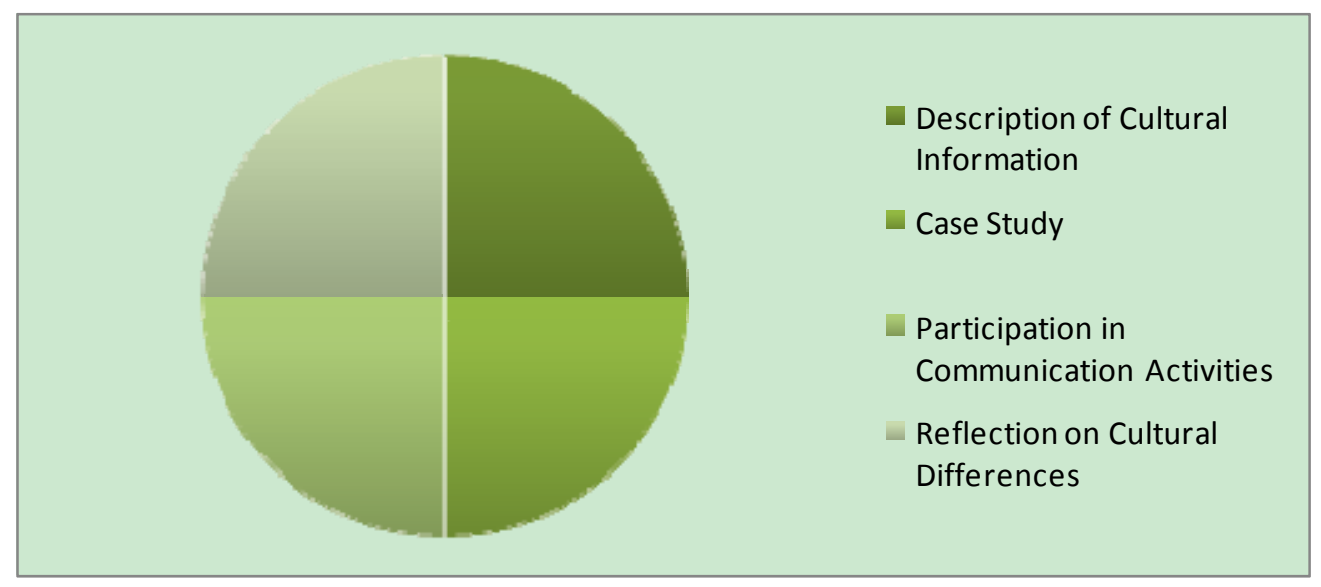

Figure 1. Intercultural teaching cycle mode

Figure 1 shows that all aspects of intercultural teaching are closely linked and interpenetrated and they constitute the whole intercultural teaching in an annular pattern. The interactive teaching approach was carried out throughout the whole teaching process. In other words, students learned learning materials interactively in the classroom, including listening and reading cultural resources, participating in case discussions and communication activities and reflecting on cultural differences. In addition, the methods of "cultural capsule" and "cultural cluster" in " $3 \mathrm{C}$ " cultural introduction methods (cultural aside, cultural capsule and cultural cluster) were adopted in the process of description of cultural information, case study and reflection on cultural differences. The "cultural capsule" method means that teachers selected an article about the culture of the target language and encouraged cultural comparisons and discussions. While cultural cluster is a cluster of themed cultural capsules, an extension and combination of cultural capsules. Let us take the cultural teaching of Unit 5 of Integrated Skills of English III as an example to elaborate the implementation of cultural teaching. Theme words of this Unit are Romance and Valentine, and the schedule of teaching activities was made according to the mode of "Cultural Knowings", as shown in Table 2. 
Table 2. Schedule of the cultural teaching of Unit V Text A

\begin{tabular}{|c|c|c|c|}
\hline $\begin{array}{l}\text { Description of cultural } \\
\text { information }\end{array}$ & Case study & $\begin{array}{l}\text { Participation in } \\
\text { communication activities }\end{array}$ & $\begin{array}{l}\text { Reflection on cultural } \\
\text { differences }\end{array}$ \\
\hline $\begin{array}{l}\text { (1) The religious origin of } \\
\text { Valentine's Day in the } \\
\text { Western countries } \\
\text { (2) The history and customs } \\
\text { of Valentine's Day } \\
\text { (3) Celebrations of the } \\
\text { modern Valentine's Day }\end{array}$ & $\begin{array}{l}\text { (1) Listening to the song } \\
\text { "Valentine's Kiss", analyzing } \\
\text { the lyrics and feeling the } \\
\text { conveyance of love and } \\
\text { romance } \\
\text { (2) Watching a dialogue of an } \\
\text { American couple when they } \\
\text { celebrated Valentine's Day } \\
\text { and finding the related } \\
\text { expressions. } \\
\text { (3) Watching movie clips of } \\
\text { "Valentine's Day" to } \\
\text { experience and understand } \\
\text { the values behind Valentine's } \\
\text { Day }\end{array}$ & $\begin{array}{l}\text { (1) Making Valentine's Day } \\
\text { cards } \\
\text { (2) Selecting Valentine's Day } \\
\text { gifts } \\
\text { (3) Having romance dating } \\
\text { (4) Speaking in English and } \\
\text { changing love gifts }\end{array}$ & $\begin{array}{l}\text { (1) Fairy-tale romance of } \\
\text { Chinese Qixi Festival (the } \\
\text { Seventh Day of the Seventh } \\
\text { Lunar Month) } \\
\text { (2) Comparing Chinese and } \\
\text { Western Valentine's Day } \\
\text { (3) Exchanging views on } \\
\text { implicit Chinese expressions } \\
\text { of love and the Western } \\
\text { people's kissing in public } \\
\text { (4) Comparing Chinese and } \\
\text { Western values of love and } \\
\text { marriage }\end{array}$ \\
\hline
\end{tabular}

During the process of teaching, we centered around the Unit theme and introduced the history, traditions and celebrations of Western Valentine's Day in the form of cultural clusters and showed some theme-related audio and video clips and asked students to discuss and summarize the cultural characteristics of Valentine's Day and Western values of love and simulated dating occasions to have first-hand cultural experience of Valentine's Day and lay the foundation for reflection on cultural differences.

In addition, students were required to make learning portfolios throughout the whole teaching process to facilitate our surveillance on and management of the teaching process. Learning portfolios were composed of learning $\log$, learning experience records, and learning contribution folders related to the theme of the unit. Contributions folders contained materials (audio, video, text or picture) related to Chinese and Western cultures, all of which are collected from the Internet, newspaper and books according to the theme of the unit. In the second week of the first semester, we made clear to the students the purpose and significance of learning portfolios and gave a brief introduction to the main contents and general building methods of learning portfolios. In the third week, we specifically introduced the practice that combined the preparation of learning portfolios with classroom cultural teaching and extracurricular reflective learning to help students develop learning plans for each unit. From the fourth to the fifteenth week, we implemented the learning portfolio teaching approach, asked students to record learning information and learning experience of each unit and collect theme-related cultural resources. In the ninth week of this period, we arranged a mid-term portfolio presentation and required students to make self-reflection and exchange and share their learning plans, learning process, learning resources, problems and solutions. In the sixteenth week, we conducted the final portfolio presentation and semester assessment, including students' self-assessment (accounting for 3\% of the total portfolio assessment score), mutual assessment among peers (accounting for $2 \%$ of the final score) and teachers' assessment (accounting for $5 \%$ of the final score). According to the assessment results, we summed up the teaching ideas and proposed measures to further improve the teaching method.

\subsection{Reflection on Intercultural Teaching}

As the intercultural teaching lasting for almost one academic year ended, we made reflection on the teaching effectiveness from two aspects. Firstly, we examine the effectiveness of intercultural teaching by reviewing the degree of improvement in intercultural consciousness during the academic year. Secondly, we reflect on issues worthy of attention in intercultural teaching.

\subsubsection{Degree of Improvement in Intercultural Consciousness}

To test the effectiveness of this intercultural teaching approach, we conducted another intercultural consciousness test at the end of the intercultural teaching. The test was made through two tools: questionnaire and communication activities in real-life scenarios. The content of this questionnaire was different from that at the end of the intercultural teaching in terms of content; because questions about "English score in college entrance exam" and "cognition of intercultural teaching" were deleted, and questions about students' attitudes toward intercultural teaching and their suggestions were added. In terms of communication activities in real-life scenarios, we arranged exchanges between our participants and students from English-speaking countries. 
Intragroup paired-sample $\mathrm{T}$ tests were conducted and the mean values and standard deviations of the two intercultural consciousness tests above mentioned were analyzed and compared to examine whether intercultural teaching can improve students' intercultural consciousness.

The paired-sample $\mathrm{T}$ test results showed that the mean values of non-linguistic behaviors and linguistic behaviors before and after intercultural teaching were 2.90, 3.50, and 2.79, 4.26 respectively. The mean values of sequential differences of non-linguistic behaviors and linguistic behaviors before and after the intercultural teaching were 0.59 and 1.47 respectively, and t values were -9.69 and -23.74 , and their concomitant probability were 0.000 , lower than the significance level of 0.05 , indicating that the test results of non-linguistic and linguistic behaviors changed significantly and were remarkably better than those before the intercultural teaching. In addition, after the intercultural teaching, students' understanding of and attitudes towards intercultural teaching changed from ignorance and repulsion into acceptance and active exploration. About $93 \%$ students endorsed intercultural teaching. A student said in his learning portfolio, "The study and practice of Chinese and Western cultures enable me to simultaneously experience the unique charms of both cultures. More importantly, I have learned how to understand and respect foreign cultures. I will learn Chinese and Western cultures by means of comparison and make positive conversations with foreigners in the future." Most students agreed that language and culture teaching can complement each other, and shared the views that "language is part of culture. Cultural learning is positive and effective, because it can enhance our interest in English, and expand our horizons and ways of thinking." However, the results of the second test showed that students did not have a completely positive attitude towards intercultural teaching, and some students were not interested in or even opposed to it. In this regard, we wrote in our teaching log, "The change in concept is a long process. With few experiences of communicating with foreigners, many students lack consciousness of the significance and role of intercultural teaching."

The first test showed that about $85 \%$ students had no experience of communicating with people from English-speaking countries, so we arranged an exchange activity to test the degree of participants' improvement in intercultural consciousness in real-life scenarios. This test was carried out in a 100-minute spoken class, where there were 11 international students and 66 Chinese students. They were divided into 11 groups, 1 international student in each group. Students were asked to start with greeting, introduced themselves and discussed the topics that could interest both sides, such as college life, employment, marriage and family. After observing and listening to these conversations, we deeply felt that the vast majority of students developed a better intercultural consciousness after nearly a year's intercultural learning. When a student was complimented for his good English proficiency, he replied with a smile, "Thank you." None of them kept silent because of shyness or replied with "No, no, no. My English is not as good as you think." When it comes to future plan, a student asked, "Don't you hope to get a good job and find a person to share your life with?" When they were asked why they answered in these ways, they replied, "It is considered impolite in Western countries to show sham modesty or keep silent when we are complimented; individual differences in sexual orientation should also be taken into account when we converse with foreigners, and we should not presume from the angle of Chinese traditional culture and values that everyone will eventually marry the opposite sex."

\subsubsection{Issues Requiring Attention in Intercultural Teaching}

This intercultural action teaching not only enhanced students' intercultural consciousness, but also improved the understanding of intercultural teaching of teachers involved in the process.

1) Cultural teaching should be combined with language teaching, and we must not favor one particularly and ignore another. Language and culture reflect the ends and means of each other in intercultural English teaching. Because English language learning itself is involved in cultural learning, we have every reason to believe thatEnglish language learning is a means of cultural learning, and cultural learning and intercultural communication are the purposes of English learning. Conversely, cultural learning provides rich, authentic and live materials and environments for English language learning. A lot of cultural materials are incorporated into English teaching materials and classrooms, not only making English learning interesting but guaranteeing the cultivation of English communicative competence (Zhang, 2007, p. 233). Therefore, language and cultural teaching should complement each other throughout the whole process from English curriculum design, arrangement to the orderly execution of classroom activities. According to students' different cognitive levels and learning needs in different stages, we may adjust properly the ratio of language teaching to cultural teaching. However, it would be incompatible with the needs of foreign language teaching and social development to train only students' language skills and ignore cultural cultivation.

2) Intercultural teaching should follow the "student-centered and teacher-guided" principle to fully arouse 
students' interest in cultural learning and promote their learning autonomy. Since the implementation of China's college English teaching reform, the roles of teachers and students and the relationship between them have undergone fundamental changes. Teachers no longer act as the dispensers of all the knowledge or the manipulators of the learning process. Meanwhile, students begin to take up responsibilities for satisfying their own learning needs rather than solely relying on teachers. By taking more responsibilities, students become more independent and are able to identify their own strengths and weaknesses in learning and thus promote the development of their language skills. Intercultural teaching should be guided by teachers to encourage students to take initiative to explore their native culture as well as foreign cultures through a variety of channels and know and identify cultural differences based on their personal experiencesfor the transformation from "ethnocentrism" to "ethnorelativism".

3) Intercultural teaching should follow the principle of "teaching students according to their aptitude" and take full account of learners' cognitive levels and language skills, and proceed from concrete and intuitive themes that are closely related to our daily life to the ideological teaching of abstract values and ways of thinking. Although participants in this study have at least 6 years of experience in English learning and have developed a certain degree of English proficiency, the sources of their knowledge about English culture are limited to the information provided by the media, books and the Internet. Therefore, they have almost no idea about intercultural concepts. For these target groups, intercultural teaching should with the textual topic to enable them to consciously absorb cultural knowledge and merge themselves into cultural environments, so students can keep themselves in a state of self-consciousness and self-reflection and gradually deepen their understanding and feeling of both Chinese culture and English culture.

4) The method of comparative analysis should be adopted in intercultural teaching. The method of comparative analysis adopted in intercultural communication studies is to compare and analyze communication behaviors of different cultures as well as rules, ways of thinking and values that determine these communication behaviors to discover the similarities and differences of cultures. Its focus is placed on the explanation of cultural differences and cultural misunderstandings as well as cultural conflicts arising from these differences and misunderstandings. By tracing the cultural origins and proposing effective methods to avoid negative cultural transfers, this method promotes intercultural understanding and adaption and thus facilitates effective intercultural communication on common grounds between the two communicating parties (Bi, 2009, p. 36). College English intercultural teaching should aim at developing intercultural mediators. Only through comparison and learning of two different cultures can we enable students to have a good understanding of the similarities and differences of two languages and cultures. Then we may feel qualified to say that we are working on increasing students' intercultural consciousness.

\section{Conclusion}

Intercultural teaching, as part of college English teaching, is a fresh attempt in China, an innovation and new development of traditional cultural teaching approach, and a fundamental need for international talents. The development course of cultural teaching and the advantages of intercultural teaching were analyzed in this paper and an experimental intercultural teaching was carried out by using the approach of action research. In combination with the issues identified in teaching, the experimental teaching approach followed the general principles of intercultural teaching with specifically-designed teaching activities, and applied the intercultural teaching mode of "Cultural Knowings", achieving remarkable results. However, the teaching effectiveness needs to be further examined due to the limitations of small samples and short experimental duration in this study. Moreover, since students' cognitive level and language skill are important factors affecting intercultural consciousness, deep and thorough studies shall be conducted in the future by taking these two factors into account.

\section{Acknowledgements}

This paper is a staged achievement of "On the application of Case Teaching Method in Intercultural Communication Course"- a project in Higher Education and Scientific study in Inner Mongolia University for the Nationalities. (License number: MDZD201409)

\section{References}

Bi, J. W. (2009). Intercultural Communication and the Second Language Teaching. Beijing: Beijing Language and Culture University Press.

Fei, X. J. (2006). Cultivation of Intercultural Awareness in College English Teaching. Chengdu: University of Electronic Science and Technology of China. 
Ferrance, E. (2000). Action Research. RhodeIsland: Northeast and Islands Regional Educational Laboratory at Brown University.

Hart, E., \& Bond, M. (1995). Action Research for Health and Social Care: A Guide to Practice. Buckingham: Open UniversityPress.

Kemmis, S., \& McTaggart, R. (1992). The Action Research Planne. Victoria: Deakin University Press.

Kramsch, C. (1998). Languageand Culture. London: Oxford University Press.

Lewin, K. (1948). Action research and minority problems. In K. Lewin (Ed.), Resolving Social Conflicts: Selected Paperson Group Dynamics (pp. 201-216). NewYork: Harper \& Row.

Liddicoat, A. J. (2004). Intercultural language teaching: Principles for practice. The New Zealand Language Teacher, (30), 17-23.

Moran, P. R. (2001). Teaching Culture: Perspectivesin Practice. Boston: Heinle \& Heinle.

Neuliep, J. W., \& McCroskey, J. C. (1997). The development of intercultural and interethnic communication apprehension scales. Communication Research Reports, (14), 145-156. http://dx.doi.org/10.1080/08824099709388656

Spair, E. (1921). Language: An Introduction to the Study of Speech. NewYork: Harcourt Brace \& Company.

Zhang, H. L. (2007). Intercultural Communication \& Foreign Language Teaching. Shanghai: Shanghai Foreign Language Education Press.

\section{Copyrights}

Copyright for this article is retained by the author(s), with first publication rights granted to the journal.

This is an open-access article distributed under the terms and conditions of the Creative Commons Attribution license (http://creativecommons.org/licenses/by/3.0/). 